\title{
ANALISIS LIKUIDITAS DALAM MENILAI KINERJA KEUANGAN KOPERASI
}

\author{
Rano Asoka \\ STIE Rahmaniyah Sekayu \\ Email: ranoasoka09@gmail.com
}

\begin{abstract}
Abstrak
Tujuan penelitian ini adalah untuk mengetahui penilaian tingkat likuiditas koperasi. Data yang digunakan dalam penelitian ini adalah data sekunder berupa laporan keuangan koperasi. Penelitian ini menggunakan teknik pengumpulan data dengan studi pustaka dan dokumentasi. Teknik analisis data yang digunakan adalah analisis kuantitatif dengan menggunakan rasio. Penelitian ini menemukan bahwa tingkat likuiditas laporan keuangan koperasi yang diukur dengan rasio lancar dan rasio cepat untuk tahun 2016 dan 2017 berada pada kategori baik.
\end{abstract}

Kata kunci : laporan keuangan koperasi, dan likuiditas.

\section{PENDAHULUAN}

\subsection{Latar Belakang Masalah}

Koperasi berfungsi membangun dan mengembangkan potensi serta kemampuan ekonomi para anggota khususnya, dan masyarakat pada umumnya serta meningkatkan kesejahteraan ekonomi dan sosial. Perkembangan dan keberhasilan dalam mengelola usaha koperasi dapat dilihat dari posisi keuangan koperasi, serta analisis data keuangan dari tahun ke tahun.

Laporan keuangan koperasi terdiri dari laporan perhitungan hasil usaha, laporan posisi keuangan, laporan perubahan ekuitas, laporan arus kas, dan catatan atas laporan keuangan. Analisis laporan keuangan bisa dilakukan dengan berbagai metode, salah satu nya adalah analisis rasio.

Analisis rasio adalah suatu teknik untuk menganalisis laporan keuangan dari suatu koperasi/badan usaha yang lain dengan menggunakan ukuran/rasio tertentu, yang bertujuan untuk mengetahui kondisi keuangan suatu koperasi. Penilaian kinerja koperasi dari aspek finansial dilakukan melalui analisis terhadap laporan keuangan. Salah satunya yaitu dengan menggunakan rasio likuiditas, yang digunakan untuk mengukur kemampuan koperasi dalam memenuhi kewajiban 
financial jangka pendek atau kemampuan perusahaan untuk melunasi hutang jangka pendek tepat pada waktunya.

Koperasi Unit Desa Sejahtera (KUD) Sejahtera menjalankan banyak bidang usaha, yaitu pemasaran/penjualan Tandan Buah Segar, jasa angkutan, waserda, Unit Simpan Pinjam, penyaluran BBM, jasa photo copy, dan penjualan alat tulis kantor. Koperasi ini didirikan dengan badan hukum Nomor 00322/BH/PAD/KOPPMPP/II/III pada tanggal 26 Februari 2007.

Berikut ini disajikan data mengenai asset lancar dan kewajiban jangka pendek periode tahun 2016 dan 2017:

\section{Tabel 1}

Koperasi Unit desa (KUD) Sejahtera

Asset Lancar dan Kewajiban Jangka Pendek

Tahun 2016-2017

(Dalam Rupiah)

\begin{tabular}{|l|r|r|}
\hline \multicolumn{1}{|c|}{ Keterangan } & \multicolumn{1}{c|}{ Tahun 2016 } & \multicolumn{1}{c|}{ Tahun 2017 } \\
\hline Asset Lancar & & \\
Kas & 47.463994 .000 & 37.540 .000 .000 \\
Bank & 7.165 .937 .976 .000 & 7.136 .503 .799 .270 \\
Deposito Bank Sumsel & 3.000 .000 .000 & 3.000 .000 .000 \\
Deposito Bank Mandiri & 0 & 1.200 .000 .000 \\
Piutang unit simpan pinjam-MAP & 113.524 .368 .000 & 87.207 .676 .000 \\
Piutang pihak lain & 2.744 .000 .000 & 2.744 .000 .000 .000 \\
Piutang unit simpan pinjam & 1.082 .178 .720 .000 & 927.442 .282 .000 \\
Persediaan & 12.140 .199 .000 & 16.645 .462 .000 \\
Total Asset & $\mathbf{1 4 . 1 6 5 . 2 4 5 . 2 5 7 . 0 0 0}$ & $\mathbf{1 5 . 1 4 9 . 3 3 9 . 2 1 9 . 2 7 0}$ \\
\hline Kewajiban Jangka Pendek & & \\
Titipan Div A & 1.028 .743 .874 .000 & 1.044 .347 .289 .000 \\
Titipan Dana Titipan THR & 157.937 .6000 .000 & 66.214 .000 .000 \\
Titipan dana PBB & 91.105 .465 .000 & 54.663 .279 .000 \\
Titipan anggota KKPA 1 & 1.752 .217 .352 .000 & 2.348 .403 .413 .270 \\
Titipan anggota KKPA 2 & 1.419 .225 .640 .000 & 1.419 .225 .640 .000 \\
Total Kewajiban Jangka Pendek & $\mathbf{5 . 2 4 9 . 2 8 4 . 0 6 4 . 0 0 0}$ & $\mathbf{4 . 9 3 2 . 8 5 3 . 6 2 1 . 2 7 0}$ \\
\hline Sumber : KUD Sejahtera 2018, & & \\
\hline
\end{tabular}

Sumber : KUD Sejahtera 2018, data diolah. 
Berdasarkan Tabel 1, diketahui total asset lancar koperasi meningkat tahun 2017 dibandingkan dengan tahun 2016, sedangkan total kewajiban koperasi mengalami perunurun tahun 2017 dibandingkan dengan tahun 2016.

Berdasarkan latar belakang di atas, maka Penulis tertarik untuk melakukan penelitiandengan judul:Analisis Likuiditas dalam Meniai Kinerja Keuangan pada Koperasi Unit Desa Sejahtera.

\subsection{Perumusan Masalah}

Berdasarkan latar belakang di atas, maka rumusan masalah dalam penelitian ini adalah bagaimana kinerja keuangan koperasi berdasarkan analisis likuiditas pada Koperasi Unit Desa Sejahtera.

\subsection{Tujuan Penelitian}

Berdasarkan uraian dari permasalahan di atas, maka tujuan penelitian ini adalah untuk mengetahui kinerja keuangan koperasi berdasarkan analisis likuiditas pada Koperasi Unit Desa Sejahtera.

\section{LANDASAN TEORI}

\subsection{Pengertian Koperasi}

Koperasi adalah badan usaha yang beranggotakan orang-orang atau badan hukum koperasi dengan melandaskan kegiatannya berdasarkan prinsip koperasi sekaligus sebagai gerakan ekonomi rakyat yang berdasarkan atas asas kekeluargaan (UU No. 25 Tahun 1992). Koperasi berperan untuk membangun dan mengembangkan potensi dan kemampuan ekonomi anggota khususnya dan masyarakat pada umumnya untuk meningkatkan kesejatheraan ekonomi dan sosial.

\subsection{Tujuan koperasi}

Berdasarkan UU Nomor 25 Tahun1992, koperasi bertujuan untuk memajukan kesejahteraan anggota pada khususnya dan masyarakat pada umumnya, serta ikut membangun tatanan perekonomian nasional dalam rangka 
mewujudkan masyarakat yang maju, adil, dan makmur berlandaskan Pancasila dan UUD 1945.

\subsection{Fungsi Koperasi}

UU Nomor 25 Tahun1992, memuat fungsi dan peran koperasi di Indonesiayaitu sebagai berikut:

1. Membangun dan mengembangkan potensi serta kemampuan ekonomi anggota pada khususnya dan masyarakat pada umumnya untukmeningkatkan kesejahteraan ekonomi dan sosial.

2. Turut serta secara aktif dalam upaya meningkatkan kualitas kehidupan manusia dan masyarakat.

\subsection{Manfaat Koperasi}

Manfaat koperasi dapat dibagi menjadi dua bidang, yaitu manfaat koperasi di bidang ekonomi dan manfaatkoperasi di bidang sosial.

1. Manfaat koperasi di bidang ekonomi :

a. Meningkatkan penghasilan anggota-anggotanya

b. Menawarkan barang dan jasa dengan harga yang lebih murah

c. Menumbuhkan motif berusaha yang berperikemanusiaan

d. Menumbuhkan sikap jujur dan keterbukaan dalam pengelolaan koperasi

e. Melatih masyarakat untuk menggunakan pendapatannya secara lebih efektifdan membiasakan untuk hidup hemat

2. Manfaat koperasi di bidang sosial :

a. Mendorong terwujudnya kehidupan masyarakat damai dan tenteram

b. Mendorong terwujudnya aturan yang manusiawi yang dibangun tidak di atashubungan-hubungan kebendaan tetapi di atas rasa kekeluargaan

c. Mendidik anggota-anggotanya untuk memiliki semangat kerja sama dan semangat kekeluargaan

\subsection{Prinsip Koperasi}

Menurut Undang-undang Nomor 25 Tahun1992 terdapat beberapa prinsip koperasi yaitu :

1. Keanggotaan koperasi bersifat sukarela dan terbuka 
2. Pengelolaan koperasi dilakukan secara demokratis

3. Sisa Hasil Usaha (SHU) yang merupakan keuntungan dari usaha yang dilakukan oleh koperasi dibagi berdasarkan besarnya jasa masing-masing anggota

4. Modal diberi balas jasa secara terbatas

5. Koperasi bersifat mandiri

\subsection{Jenis-jenis Koperasi}

Menurut Rudianto (2010), koperasi dapat dikelompokkan menjadi empat, yaitu:

1. Koperasi Simpan Pinjam

2. Koperasi Konsumen

3. Koperasi Pemasaran

4. Koperasi Produsen

\subsection{Laporan Keuangan Koperasi}

Menurut Munawir (2010) Laporan keuangan adalah hasil dari proses akuntansi yang dapat digunakan sebagai alat untuk berkomunikasi antara data keuangan atau aktivitas suatu perusahaan dengan pihak-pihak yang berkepentingan dengan data keuangan. Laporan keuangan koperasi terdiri dari, perhitungan hasil usaha, laporan posisi keuangan/neraca, laporan perubahan kekayaan bersih, laporan arus kas, dan catatan atas laporan keuangan.

\subsection{Konsep Kinerja Keuangan}

Menurut Fahmi (2011), Kinerja keuangan adalah suatu analisis yang dilakukan untuk melihat sejauh mana suatu perusahaan telah melaksanakan dengan menggunakan atura-aturan pelaksanaan keuangan secara baik dan benar.Salah satu alat analisis kinerja keuangan adalah analisis rasio, seperti rasio likuiditas.

\subsection{Rasio Likuiditas}


Kasmir (2012), mengemukakan bahwa rasio likuiditas adalah kemampuan perusahaan untuk membayar kewajiban-kewajibannya yang segera harus dipenuhi. Analisis rasio likuiditas ini terdiri dari rasio lancar, rasio cepat, rasio kas, dan rasio perputaran kas. Rasio likuiditas yang digunakan dalam penelitian ini adalah rasio lancar dan rasio cepat.

1. Rasio lancar

Rasio ini membandingkan kemampuan asset lancar dalam memenuhi kewajiban utang lancar pada saat jatuh tempo. Rumus untuk menetukan nilai rasio lancar untuk melihat tingkat likuiditas adalah sebagai berikut :

$$
\text { Rasio lancar }=\frac{\text { Asset Lancar }}{\text { Utang Lancar }} \times 100 \%
$$

\section{Rasio Cepat}

Rasio ini membandingkan kemampuan asset lancar setelah dikurangi dengan persediaan dalam memenuhi kewajiban lancar pada saat jatuh tempo. Rumus yang digunakan adalah sebagai berikut :

$$
\text { Rasio cepat }=\frac{\text { Asset Lancar }- \text { Persediaan }}{\text { Utang Lancar }} \times 100 \%
$$

\subsection{Kerangka Pemikiran}

Kerangka pemikiran dalam penelitian ini disajikan pada Gambar 1 sebagai berikut:

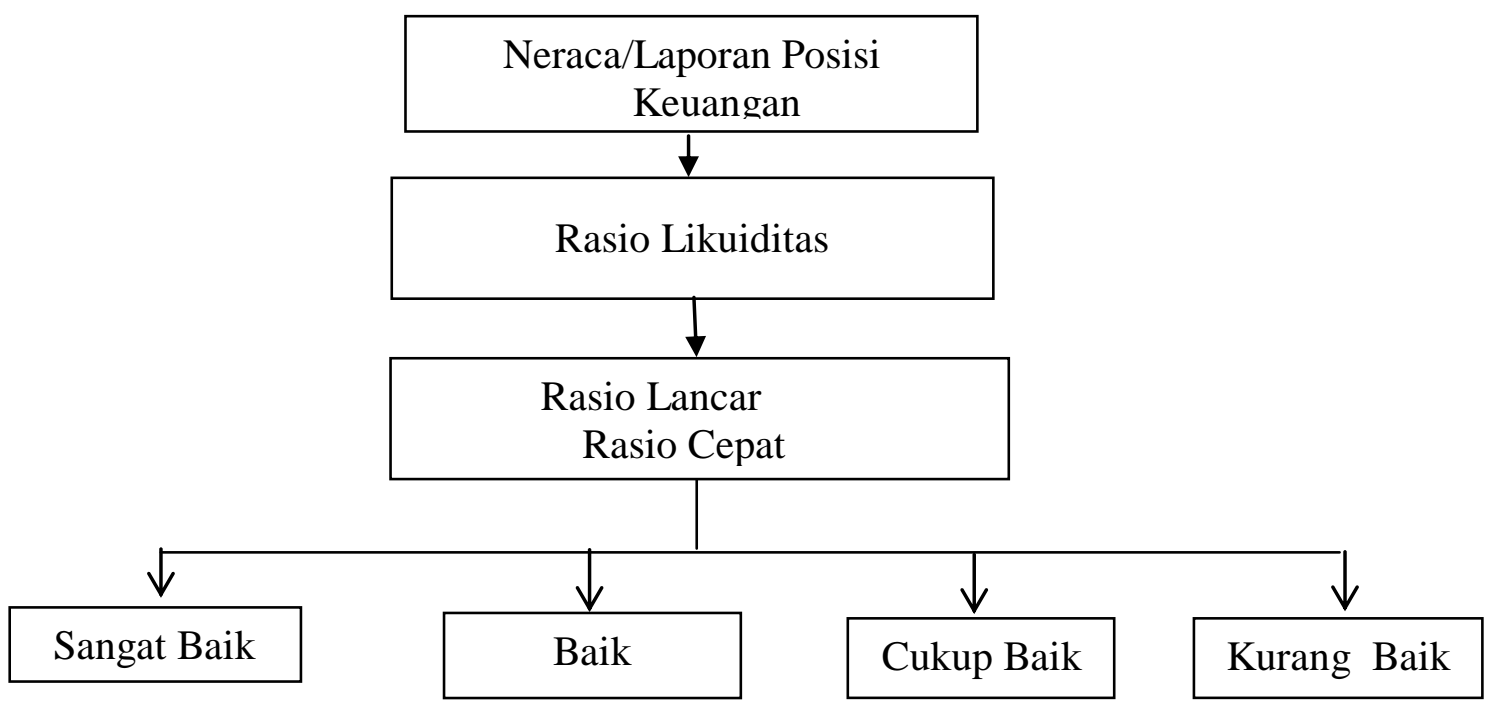

Gambar 1

Kerangka Pemikiran 


\section{METODOLOGI PENELITIAN}

\subsection{Lokasi dan Waktu Penelitian}

Penelitian ini dilakukan pada Koperasi Unit Desa(KUD) Sejahtera yang beralamat di Kelurahan Babat kecamatan Babat Toman Kabupaten Musi Banyuasin. Waktu penelitian dilakukan selama 1 (satu) bulan.

\subsection{Metode Penelitian}

Metode penelitian yang digunakan yaitu metode kuantitatif menggunakan laporan keuangan pada KUD Sejahtera untuk mengukur tingkat likuiditas laporan keuangan koperasi.

\subsection{Jenis dan Sumber Data}

Sumber data yang digunakan Penulis pada penelitian ini adalah data sekunder. Data sekunder yang digunakan Penulis pada penelitian ini adalah laporan neraca Tahun2016-2017.

\subsection{Teknikpengumpulan data}

Teknik pengumpulan data yang digunakan Penulis pada penelitian ini adalah sebagai berikut :

1. Dokumentasi

2. Studi Kepustakaan

\subsection{Teknik Analisis Data}

Penulis menggunakan metode kuantitatif untuk menilai tingkat likuiditas laporan keuangan koperasi dengan menggunakan rasio.

\section{HASIL DAN PEMBAHASAN}

Tingkat likuiditas pada koperasi bisa diukur dengan menggunakan analisis rasio. Dalam penelitian ini, penulis menggunakan rasio lancar dan rasio cepat. Berikut disajikan perhitungan rasio lancar dan rasio cepat tahun 2016 dan 2017:

Rasio Lancar $\quad=\underset{\text { Utang lancar }}{\text { Asset Lancar }} \times 100 \%$


Jurnal Ilmiah Akuntansi Rahmaniyah (JIAR)

Vol. 2 No.1, Desember 2018, 82 - 91

Asoka

Tahun 2016

$$
\begin{aligned}
& =\frac{14 \cdot 165.245 .257}{5.249 .284 .064} \times 100 \% \\
& =269,85 \%
\end{aligned}
$$

Tahun 2017

$$
\begin{aligned}
& =\frac{15 \cdot 149.339 .219,27}{4.932 .853 .621,27} \times 100 \% \\
& =307,11 \%
\end{aligned}
$$

Rasio cepat

$$
\text { = Asset Lancar-persediaan } \times 100 \%
$$

Utang lancar

Tahun 2016

$$
\begin{aligned}
& =\frac{14 \cdot 165.245 .257-12.140 .199}{5.249 .284 .064} \times 100 \% \\
& =269,62 \%
\end{aligned}
$$

Tahun 2017

$$
\begin{aligned}
& =\frac{15.149 .339 .219,27-16.645 .462}{4.932 .853 .621,27} \times 100 \% \\
& =306,77 \%
\end{aligned}
$$

Berdasarkan perhitungan di atas, maka dapat disusun rekapitulasi hasil perhitungan rasio lancar dan rasio cepat :

Tabel 2

\section{KUD Sejahtera}

\section{Rekapitulasi Rasio Lancar dan Rasio Tetap}

Tahun 2016-2017

\begin{tabular}{|l|l|l|l|}
\hline Tahun & \multicolumn{1}{|c|}{ Rasio likuiditas } & \multicolumn{1}{c|}{ Rasio } & \multicolumn{1}{|c|}{ keterangan } \\
\hline 2016 & Rasio lancar & $269,85 \%$ & Baik \\
\hline 2016 & Rasio cepat & $269,62 \%$ & Baik \\
\hline 2017 & Rasio lancar & $307,11 \%$ & Baik \\
\hline 2017 & Rasio cepat & $306,77 \%$ & Baik \\
\hline
\end{tabular}

Sumber: KUD Sejahtera, 2019, Data Diolah

Berdasarkan hasil rekapitulasi perhitungan rasio likuiditas menggunakan rasio lancar dan rasio cepat dapat dijelaskan bahwa KUD Sejahtera berada dalam 
kategori sangat baik. KUD Sejahtera memiliki asset lancar dalam jumlah yang sangat besar dibandingkan dengan utang lancar yang dimilikinya sehingga keadaan sangat menguntungkan bagi koperasi. Asset lancar dalam jumlah besar dimiliki koperasi dalam bentuk simpanan kas di bank, deposito pada Bank Sumsel, piutang unit simpan pinjam, serta deposito pada Bank Mandiri. Nilai deposito dengan nominal diatas satu milyar memberikan kontribusi pendapatan bunga dalam jumlah yang besar dengan nominal ratusan juta setiap tahunnya.

Tersedianya asset lancar dalam jumlah yang besar memberikan dampak positif koperasi dalam menjalankan kegiatan operasionalnya, bahkan pada tahun 2017, koperasi ini mampu melaksanakan berbagai kegiatan sebagai berikut:

a. Pembangunan pagar kantor KUD Sejahtera

b. Pembangunan kantor KUD Sejahtera

c. Pembangunan kantor permanen devisi C

d. Pemetaan ulang areal KKPA I dan II kebun KUD Sejahtera

e. Pembangunan barak divisi A sebanyak 6 pintu

f. Pembangunan kantor devisi B

g. Pembelian 2 (dua) unit mobil.

Selain pembangunan fisik, koperasi ini juga mendukung kegiatan pendidikan dengan memberikan pelayanan terhadap siswa yang magang atau melakukan praktek di koperasi ini. Selama tahun 2017 terdapat tiga sekolah yang diterima magang dikoperasi ini, yaitu siswa SMK Nurul Huda Babat Toman, siswa SMK 1 Sanga Desa, dan siswa SMK 1 Lawang Wetan.

\section{SIMPULAN DAN SARAN}

\subsection{Kesimpulan}

Berdasarkan hasil penelitian dan pembahasan, maka dapat disimpulkan bahwa secara likuiditas koperasi berada dalam kategori sangat baik karena koperasi memiliki aset lancar yang mampu memenuhi kewajiban jangka pendeknya. Koperasi ini juga dikelola dengan baik sehingga koperasi mampu berkembang dan melaksanakan program pembangunan fisik dan non fisik.

\subsection{Saran}


Berdasarkan kesimpulan diatas, maka Penulis memberikan saran agar koperasi mampu meningkatkan pencapaian untuk tahun-tahun berikutnya. Koperasi ini memiliki potensi yang besar untuk mampu berkembang jika pengelolaan dilakukan dengan baik, sehingga para anggota merasakan manfaat yang besar dari kegiatan koperasi.

\section{DAFTAR PUSTAKA}

Fahmi, Irham. 2011. Manajemen Kinerja Keuangan Teori dan Aplikasi. Bandung:Alfabeta.

Kasmir. 2012. Analisis Laporan Keuangan. Jakarta: Rajawali Pers.

Munawir, S. 2010. Analisis Laporan Keuangan. Yogyakarta:Liberty

Rudianto. 2010. Akuntansi Koperasi. Jakarta: Erlangga

Sugiyono. 2017. Metode Penelitian Kuantitatif Kualitatif dan R\&D. Bandung: Alfabeta.

Undang-Undang No. 25 Tahun 1992 Tentang Perkoperasian 